Article

\title{
Investigating the Association between Outdoor Environment and Outdoor Activities for Seniors Living in Old Residential Communities
}

\author{
Shiwang $\mathrm{Yu}^{1}{ }^{(\mathbb{D})}, \mathrm{Na} \mathrm{Guo}^{2}$, Caimiao Zheng ${ }^{1}$, Yu Song ${ }^{3}$ and Jianli Hao ${ }^{4, *(D)}$ \\ 1 School of Civil Engineering, Sanjiang University, Nanjing 210012, China; Sherwood.s.w.yu@gmail.com (S.Y.); \\ 12017082031@stu.sju.edu.cn (C.Z.) \\ 2 College of Economic and Management, Nanjing Institute of Industry Technology, Nanjing 210023, China; \\ Guon@niit.edu.cn \\ 3 XIPU Institution, Xi'an Jiaotong-Liverpool University, Suzhou 215123, China; yu.song@xjtlu.edu.cn \\ 4 Department of Civil Engineering, Xi'an Jiaotong-Liverpool University, Suzhou 215123, China \\ * Correspondence: jianli.hao@xjtlu.edu.cn
}

Citation: Yu, S.; Guo, N.; Zheng, C.; Song, Y.; Hao, J. Investigating the Association between Outdoor Environment and Outdoor Activities for Seniors Living in Old Residential Communities. Int. J. Environ. Res. Public Health 2021, 18, 7500. https:/ / doi.org/10.3390/ijerph18147500

Academic Editors: Fermina Rojo-Pérez, Gloria Fernández-Mayoralas,

Diego Sánchez-González and Paul B. Tchounwou

Received: 8 April 2021 Accepted: 12 July 2021 Published: 14 July 2021

Publisher's Note: MDPI stays neutral with regard to jurisdictional claims in published maps and institutional affiliations.

Copyright: (c) 2021 by the authors. Licensee MDPI, Basel, Switzerland. This article is an open access article distributed under the terms and conditions of the Creative Commons Attribution (CC BY) license (https:// creativecommons.org/licenses/by/ $4.0 /)$.

\begin{abstract}
Many seniors live in old residential communities (ORCs) with low-quality outdoor environment (OE), which hinders the residents' outdoor daily activities (ODAs). This paper empirically investigates the association of OE on ODAs for seniors living in ORCs. A questionnaire was designed and distributed in six central districts of Nanjing city. A total of 258 questionnaires was finally collected, of which $60.08 \%, 29.46 \%, 9.69 \%$, and $0.78 \%$ respondents were scattered into four age groups $(61-69,70-79,80-89$, and $\geq 90)$, respectively. Based on reliability analysis, correlation analysis, and regression analysis, the results show that: (1) social activities are mainly associated with noise; (2) leisure activities are significantly associated with road accessibility, slip-resistance measures, greenery, and staff; (3) utilitarian-type activities are significantly associated with stairway accessibility, slip-resistance measures, greenery, and seating; (4) there is a significant association between nature-exposure activities and layout, greenery, and poor air quality. The findings could guide Chinese officials when renewing ORCs by addressing the most important outdoor environmental factors associated with ODAs.
\end{abstract}

Keywords: outdoor environment; daily outdoor activities; old residential communities; seniors

\section{Introduction}

China has become an aging society, with 264.02 million seniors aged 60 years and over in 2020 [1], and it is estimated that the number of seniors will increase to 500 million by 2050 [2]. Such a severe aging population can cause problems in society due to a weakened supportive environment in terms of physical, psychological, financial, medical, and social needs. Evidence shows that an aging population increase is followed by a decrease in the birth rate, giving rise to even more serious social problems [3]. The number of seniors with inadequate support in China has significantly increased in recent years due to government policies resulting in couples having fewer children and people being too busy to practically care for their elderly parents $[4,5]$.

Although there is a trend of urban renewal and consequential residential resettlements in China, most seniors prefer to stay in the home where they have lived for an extended period and where, for financial and psychological reasons, they can live with dignity [6,7]. However, most of their apartments are located in old residential communities (ORCs) where the outdoor environment $(\mathrm{OE})$ barely exists and cannot adequately support them as they grow older. According to the General Office of the State Council of the People's Republic of China, ORCs refer to residential communities that were built in an earlier age, are poorly maintained, have no management, lack municipal and community service facilities, and where residents have a strong desire for renewal [8]. Compared to younger 
residents who go out to work each day, seniors spend more time living in ORCs. The outdoor daily activities (ODAs) of seniors in ORCs are significantly associated with the outdoor environment in ORCs [9]. However, unlike the institutions for the older adults including nursing homes and home for the aged, which are specifically designed for the older adults, the quality of the outdoor environment in these OCRs is quite poor and unfriendly to the residents, especially the older ones. Scholars in China have reported that poor the quality of facilities in ORCs are troubling for many older residents [10]. To meet the desire of the people for a better-quality life, the State Council issued "Guiding Opinions of the General Office of the State Council on Comprehensively Promoting the Renewal of Old Residential Communities in Cities and Towns" to improve the facilities of ORCs. This policy is especially beneficial for the older adults, since they make up the majority of residents living in ORCs [11].

There have been many studies dealing with the association of the living environment in ORCs on seniors' quality of life from city planning and psychological aspects [12-14], and $\mathrm{OE}$ factors for older adults (accessibility, the physical environment, and supporting facilities) have been widely studied in developed regions [15-18]. However, unlike communities in other countries, most of the ORCs in China are gated communities, and their $\mathrm{OE}$, which is surrounded by a guarded gate and wall or fence, is jointly owned by all the homeowners [19]. Although residents living in these gated communities enjoy the benefits of being away from the disturbance of public transportation and strangers, they have to pay for the cost of the management and maintenance of the OE. One of the significant reasons for the poor quality of OE in ORCs is the lack of effective management and maintenance due to a lack of financial resources. Furthermore, due to different culture, customs, and lifestyle, the common outdoor environment factors between China and other countries are usually not consistent, and therefore, findings from other types of residential communities cannot be applied to OCRs in China. Moreover, the existing ORC-related research has mostly focused on a sponge-style community approach, evaluation methods, and public participation [20-23]. There is a scarcity of studies focusing on the association between OE in ORCs and seniors' outdoor daily activities. Given the large size and fast growth of the older population and plenty of ORCs in China, there is a need to investigate ways to improve the OE of ORCs in order to encourage more ODAs for older adults.

\section{Literature Review}

\subsection{Outdoor Environment Factors}

Previous studies have found many outdoor environment factors associated with the daily life of seniors. These factors are classified as either accessibility, the physical environment, or supporting facilities.

The accessibility of a residential community refers to the layout and elevation design of the buildings and outdoor environment to provide an accessible environment of freedom, communication, and community $[18,24,25]$. Demura et al. (2012) found that stairway accessibility could help seniors avoid tripping or slipping when walking up and down [26]. A reasonable residential layout leads to an optimized solution across several conflicting criteria by taking care of most residents' interests and providing a convenient and safe environment for their daily activities, while a poor layout can cause inconvenience and trouble to the residents [27-29]. Inaccessible roads/paths with uneven surfaces, curbs, and potholes will pose a hazard to residents, especially seniors [30,31]. All the factors mentioned regarding accessibility, significantly contribute to a senior's decision to pursue outdoor daily activities.

The outdoor physical environment, which includes lighting, noise, and air quality, is inevitably associated with the physical comfort of outdoor spaces [32,33]. Poor lighting along roads/paths could give rise to difficulties and even be hazardous for seniors [34]. Noise, which can be classified as unwanted sound, often interrupts on-going activities and induces annoyance [35,36]. Air quality refers to the physical, chemical, and biological characteristics of air, which is important for people's health and activities [37]. Older 
adults usually experience the aforementioned outdoor physical environment factors when conducting their outdoor activities.

Supporting facilities in ORCs provide a convenient and comfortable environment for its senior residents, the most common of which are greenery, handrails, fitness equipment, security, and seating [18]. Senior residents can be quickly drawn to the greeneries to rest, socialize, and take exercise $[38,39]$. Since seniors are more prone to fall without the help of handrails due to their decreased physical ability [40], certified handrails could be installed to provide a supportive environment for seniors [41]. A lack of security measures can trigger fear or worry and make seniors hesitant to go outside [42]. Cleaning work provides a tidy environment by removing trash from public areas where residents usually walk or stay around [43]. Fitness equipment provides an opportunity for people to take part in leisure activities, while a lack of it may lead to less physical activities for seniors [44,45]. Availability of seating is a significant concern for older adults when they think about going out $[46,47]$. It is very important for facilities management staff to behave in a friendly manner, respond to the residents' concerns quickly, and try to meet their needs [48]. Failing to do so often leads to residents feeling dissatisfied and even to complaints [49]. All of the aforementioned supporting facilities play a significant part in promoting residents' satisfaction with their daily lives.

\subsection{Outdoor Daily Activities}

Outdoor daily activities are necessary for seniors' physical and social needs [50]. There are broadly four types of ODAs for seniors: (1) social activities; (2) leisure activities; (3) activities of daily living, and (4) nature-exposure activities [51-55]. These ODAs are essential for seniors' quality of life.

Social activities refer to the activities focusing on social contact with other people in different ways, including meeting with family members and gathering with friends [56]. Chatting with neighbors and social interaction with friends in outdoor spaces are everyday social activities for seniors [57,58]. Participating in social activities is an efficient way to maintain and improve social relations with health benefits [59]. Frequent participation in social activities has been shown to contribute to a decreased risk of dementia [60].

Leisure activities are very important to the physical and mental wellbeing of seniors [61,62]. There are many kinds of leisure activities, including tai chi, Mahjong, cards, walking, gardening, shopping, and vigorous exercise [63]. Regular participation in leisure activities can contribute to many health and social benefits, such as happiness, life satisfaction, and even a lower risk of dementia $[64,65]$. Taking part in leisure activities provides seniors with opportunities to participate in society and to lead a fuller life.

Seniors usually spend a lot of time at home performing basic activities of daily living and need to go outside to participate in utilitarian-type activities (UTA), such as using public transportation, going to the bank, and shopping for groceries [52,66]. However, seniors' utilitarian-type activities can be stymied by environmental barriers, such as poor road conditions or long distances $[42,67,68]$. A supportive environment is necessary for seniors to perform utilitarian-type activities.

Nature-exposure activities (NEAs) refer to the activities closely connected with the natural environment, including sunshine, water, greenery, and animals. Seniors can take part in nature-exposure activities in many ways, such as exposure to the sun, enjoying natural elements (garden/landscaped areas), and listening to the sound of birds and running water $[69,70]$. Evidence shows that NEAs are conducive to improved happiness, satisfaction, and wellbeing, while also helping to control anger, stress, and blood pressure [71-74].

\section{Methodology}

\subsection{Conceptual Model}

Relevant literature reveals four types of outdoor daily activities of older adults associated with accessibility, physical environment, and supporting facilities in different living environments. A conceptual model is proposed to explain the association between outdoor 
environment and ODAs (social activities, leisure activities, activities of daily living, and nature-exposure activities) for seniors. As such, the hypothesis for this research is that there is a significant association between outdoor environment factors of OCRs and the outdoor daily activities (ODAs) of seniors. A conceptual model is shown in Figure 1.

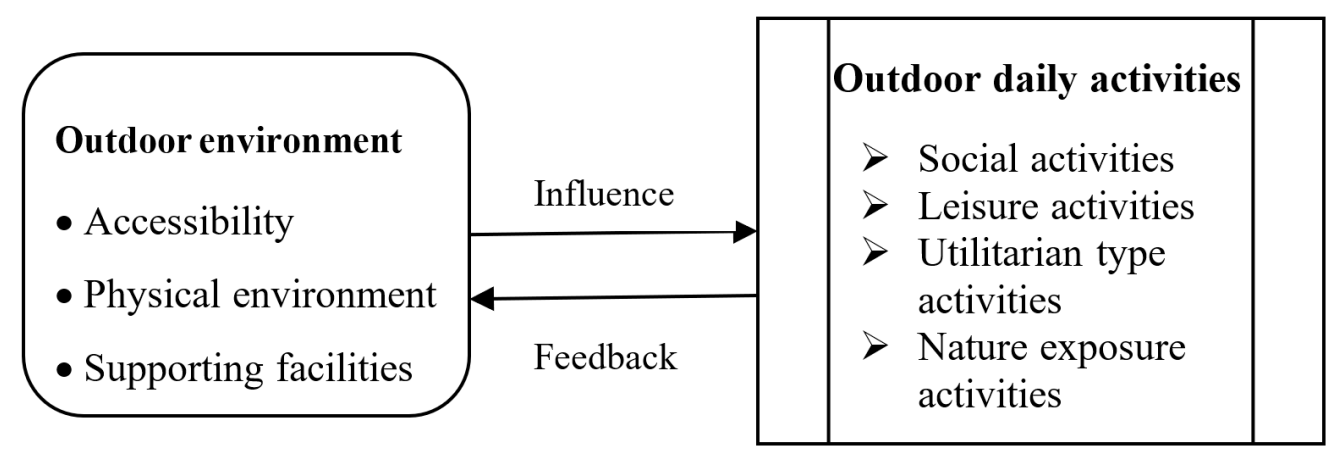

Figure 1. Conceptual model of OE and ODAs for seniors in ORCs.

\subsection{Survey Design}

A questionnaire was created for investigating the association between OE on ODAs for seniors, which included: (1) demographic characteristics, (2) outdoor daily activities components, and (3) outdoor environment components.

To collect the background information of respondents, the first part of the questionnaire sought demographic characteristics of respondents, namely gender, age, education level, and period of residence in their residential community. In the second section, four types of ODAs, namely social activities, leisure activities, outdoor activities of daily living, and nature-exposure activities were adopted based on previous studies [51-54,75]. The third part of the questionnaire included fourteen OE factors based on a review of relevant literature, China's "Property Management Regulations" and "Evaluation Standards for Service Quality of Provincial Demonstration Facilities Management Projects in Jiangsu Province" [18,76-79]. All the questions were slightly adjusted to fit the actual situation of the ODAs and outdoor environment in ORCs in China (refer to Table 1). More details of questionnaire development can be found in supplementary file S1. A total of 16 questions regarding ODAs and 53 questions with respect to outdoor environment were included in the questionnaire. A five-point Likert scale was adopted to measure the respondents' perception on the items of the questionnaire where 1 indicated extremely infrequently or strongly disagree and 5 indicated extremely frequently or strongly agree. The score for the level of agreement with each OE component and ODAs domain was calculated by taking the average of the ratings of relevant items.

Table 1. Factors adopted in this study and their sources.

\begin{tabular}{ccc}
\hline Category & Factors & Source \\
\hline \multirow{3}{*}{ Outdoor daily activities } & ODAS1-Social activities & Wen et al., 2010 [75] \\
& ODAS2-Leisure activities et al., 2010 [75] \\
& ODAS3-Utilitarian-type activities & Mahmood et al., 2012, Zhao et al., 2017 [66,80] \\
& WDAS4-Nature-exposure activities & Leung et al., 2010 2016, 2017 [81-83] \\
\hline Accessibility & F1-Stairway accessibility & Brownson et al., 2004, Laura N. Gitlin, 2001 [84,85] \\
& F2-Road/path accessibility & Leung et al., 2016 [81] \\
\hline Physical environment & F4-Slip-resistance measures & Ma et al., 2018 [87] \\
& Sun, 2016 [88]
\end{tabular}


Table 1. Cont.

\begin{tabular}{ccc}
\hline Category & Factors & Source \\
\hline & F8-Greenery & DHURDJP, 2019 [78] \\
& F9-Handrail & Leung et al., 2019 [89] \\
Supporting facilities & F10-Security & DHURDJP, 2019 [78] \\
& F11-Cleaning & DHURDJP, 2019 [78] \\
& F12-Fitness equipment & Tang, 2018 [90] \\
& F13-Seating & Tang, 2014 [91] \\
& F14-Staff & DHURDJP, 2019 [78] \\
\hline
\end{tabular}

\subsection{Sample}

To select a representative sample, the stratified random sampling method was employed in this research [61]. Sixteen ORCs from six districts in the city of Nanjing were finally selected with the following choice criteria: (1) completion time; (2) community size; (3) number of the residents; (4) location. Senior respondents in these OCRs were selected with the following criteria: (1) age 60 years and above); (2) minimum one year of residency; (3) state of health. State of health was adopted as a threshold so that only those seniors whose health allowed them to stay in the outside environment in ORCs were invited to participate in this study. Residents who rarely went outside because of serious illness, such as dementia or physical disability, were not considered in this study. The survey was conducted between March and July 2019.

Many seniors may have difficulties in filling out the questionnaire due to vision problems and/or poor education. To improve the response rate and ensure each respondent fully understood the meaning of each question, where considered necessary, questionnaires were distributed personally to respondents by well-trained investigators who explained every question in the questionnaire so that the respondents could fully understand and offer the most appropriate response.

From the 600 distributed questionnaires, 258 valid ones were returned giving a response rate of $43 \%$. Pre-analysis screening was firstly conducted to check the missing data. No patterns were found in the missing data, and all the missing data were dispersed randomly. Mean substitution was employed to deal with missing data during data analysis, which has been adopted in some studies (e.g., [92]). Among the four age groups of respondents, the first age group of 60- to 69-year-olds accounted for the biggest proportion at $60.08 \%$, which was followed by the second age group of 70 - to 79 -year-olds at $29.46 \%$. The third age group of 80 - to 89 -year-olds and the fourth age group of 90 plus were $9.69 \%$ and $0.78 \%$, respectively. Detailed information of the respondents is listed in Table 2.

Table 2. Detailed information of respondents.

\begin{tabular}{cccc}
\hline Items & Details & Amount & Proportion (\%) \\
\hline Age & $61-69$ & 155 & $60.08 \%$ \\
& $70-79$ & 76 & $29.46 \%$ \\
& $80-89$ & 25 & $9.69 \%$ \\
& $\geq 90$ & 2 & $0.78 \%$ \\
\hline Gender & Male & 127 & $49.22 \%$ \\
& Female & 131 & $50.78 \%$ \\
\hline \multirow{2}{*}{ Period of residence } & $1-5 \mathrm{y}$ & 42 & $16.28 \%$ \\
& $6-10 \mathrm{y}$ & 33 & $12.79 \%$ \\
& $11-15 \mathrm{y}$ & 108 & $41.86 \%$ \\
& $16-20 \mathrm{y}$ & 26 & $10.08 \%$ \\
& $>20 \mathrm{y}$ & 49 & $18.99 \%$ \\
\hline
\end{tabular}


Table 2. Cont.

\begin{tabular}{cccc}
\hline Items & Details & Amount & Proportion (\%) \\
\hline Education level * & Primary school & 120 & $46.88 \%$ \\
& Junior middle school & 73 & $28.52 \%$ \\
& Senior middle school & 56 & $21.88 \%$ \\
& Bachelor and above & 7 & $2.73 \%$ \\
\hline Marital status & Never married & 3 & $1.16 \%$ \\
& Married & 198 & $76.74 \%$ \\
& Widowed & 57 & $22.09 \%$ \\
\hline Faith & Christianity & 6 & $2.33 \%$ \\
& Buddhism & 21 & $8.14 \%$ \\
& Marxism & 18 & $6.98 \%$ \\
& No faith & 208 & $80.62 \%$ \\
& Others & 5 & $1.94 \%$ \\
\hline
\end{tabular}

Note: * -2 were missing.

Bonferroni adjustment was made to control Type I error. The questionnaire comprised 69 questions, and the adjusted $p$-value was 0.0007 (0.05/69). According to Levene's test, there was no difference in the variables for the respondents in ORCs, indicating that the variable data had variability and homogeneity (refer to the supplementary file S2). Based on this, the variable data were combined in this study.

\section{Results}

\subsection{Reliability Test of the OE Factors and the ODAs Domains}

Reliability analysis was employed during data analysis to check the extent to which items in the questionnaire were related to each other and to provide an overall index of the internal consistency of the scale. Cronbach's alpha was adopted to measure the reliability of each factor, and the value of 0.6 was taken as the threshold $[93,94]$. After confirming the reliability of the construct, all the item ratings were summed up to predict the $14 \mathrm{OE}$ factors: stairway accessibility (F1), road accessibility (F2), layout (F3), slip-resistance measures (F4), noise (F5), poor air quality (F6), lighting (F7), greenery (F8), handrail (F9), security (F10), cleaning (F11), fitness equipment (F12), seating (F13), and staff (F14) (see Table 3). Four types of ODAs, social activities (ODA1), leisure activities (ODA2), utilitarian-type activities (ODA3), and nature-exposure activities (ODA4), were also identified from the reliability analysis (see Table 4).

Table 3. Reliability analysis of OE factors in ORCs.

\begin{tabular}{|c|c|c|c|c|}
\hline Factors & Items & Details & Valid Observations & Alpha $(\alpha)$ \\
\hline F1—Stairway accessibility & $\begin{array}{l}1 . \\
2 . \\
3 . \\
4 .\end{array}$ & $\begin{array}{c}\text { Seniors using wheelchair or walking stick can go } \\
\text { through } \\
\text { No stuff stacked along the stairway } \\
\text { Tiles used in stairway was non-slip } \\
\text { Ramps were set at steps }\end{array}$ & 252 & 0.695 \\
\hline F2-Road/path accessibility & $\begin{array}{l}5 . \\
6 . \\
7 . \\
8 .\end{array}$ & $\begin{array}{l}\text { Roads/paths are easy to walk on } \\
\text { Manhole covers are kept well } \\
\text { No hollow and holes on the pavement } \\
\text { No obstacles on the road }\end{array}$ & 258 & 0.809 \\
\hline F3-Layout & $\begin{array}{l}9 . \\
10 . \\
11 . \\
12 . \\
13 .\end{array}$ & $\begin{array}{c}\text { Overall layout of the ORC } \\
\text { Rationality of the exits } \\
\text { Rationality of the green area } \\
\text { Rationality of the road } \\
\text { Rationality of the fitness equipment arrangement }\end{array}$ & 253 & 0.866 \\
\hline F4_Slip-resistance measures & $\begin{array}{l}14 . \\
15 . \\
16 .\end{array}$ & $\begin{array}{l}\text { Slip-resistance measures of in and out the building } \\
\text { Slip-resistance measures on the road } \\
\text { Slip-resistance measures on the steps and ramps }\end{array}$ & 257 & 0.936 \\
\hline F5-Noise & $\begin{array}{l}17 . \\
18 . \\
19 .\end{array}$ & $\begin{array}{c}\text { Decoration noise } \\
\text { Transportation noise } \\
\text { Domestic noise }\end{array}$ & 258 & 0.763 \\
\hline
\end{tabular}


Table 3. Cont.

\begin{tabular}{|c|c|c|c|c|}
\hline Factors & Items & Details & Valid Observations & Alpha $(\alpha)$ \\
\hline F6-Poor air quality & $\begin{array}{l}20 . \\
21 . \\
22 .\end{array}$ & $\begin{array}{l}\text { Life waste odors } \\
\text { Pungent odor from nearby factory } \\
\text { Dust and smog in the ORC }\end{array}$ & 257 & 0.910 \\
\hline F7-Lighting & $\begin{array}{l}23 . \\
24 . \\
25 . \\
26 .\end{array}$ & $\begin{array}{l}\text { Lighting on the road at night } \\
\text { Lighting on the public recreational area at night } \\
\text { Lighting in the stairway at daytime } \\
\text { Lighting in the stairway at night }\end{array}$ & 256 & 0.938 \\
\hline F8-Greenery & $\begin{array}{l}27 . \\
28 . \\
29 . \\
30 .\end{array}$ & $\begin{array}{l}\text { Green coverage situation in the ORC } \\
\text { Maintenance of the greenery } \\
\text { Beauty of the greenery } \\
\text { Quality of greenery maintenance }\end{array}$ & 205 & 0.982 \\
\hline F9-Handrail & $\begin{array}{l}31 . \\
32 . \\
33 .\end{array}$ & $\begin{array}{l}\text { Handrails along the stairway } \\
\text { Handrails along the steps outside the building } \\
\text { Handrails along the long ramps }\end{array}$ & 244 & 0.780 \\
\hline F10-Security & $\begin{array}{l}34 . \\
35 . \\
36 . \\
37 . \\
38 .\end{array}$ & $\begin{array}{l}\text { Reliability of the fence around the ORC } \\
\text { Reliability of building cell gate } \\
\text { The real-time monitoring of the ORC } \\
\text { Reliability of the security systems } \\
\text { Regular check and registration at the ORC gate }\end{array}$ & 206 & 0.884 \\
\hline F11-Cleaning & $\begin{array}{l}39 . \\
40 . \\
41 .\end{array}$ & $\begin{array}{l}\text { Dustmen clean the road regularly } \\
\text { The dustman emptied the dustbin every day } \\
\text { The dustman cleaned the stairway every day }\end{array}$ & 257 & 0.882 \\
\hline F12-Fitness equipment & $\begin{array}{l}42 . \\
43 . \\
44 . \\
45 .\end{array}$ & $\begin{array}{l}\text { Convenience of fitness equipment } \\
\text { Variety of fitness equipment } \\
\text { Safety of fitness equipment } \\
\text { Maintenance of fitness equipment }\end{array}$ & 247 & 0.955 \\
\hline F13-Seating & $\begin{array}{l}46 . \\
47 . \\
48 .\end{array}$ & $\begin{array}{l}\text { Quantity of seats } \\
\text { Quality of seats } \\
\text { Location of seats }\end{array}$ & 257 & 0.959 \\
\hline F14-Staff & $\begin{array}{l}49 . \\
50 . \\
51 . \\
52 .\end{array}$ & $\begin{array}{c}\text { Quantity of staff } \\
\text { Quality of staff } \\
\text { Attitude of staff to seniors } \\
\text { Processing efficiency of residents' concerns }\end{array}$ & 254 & 0.896 \\
\hline
\end{tabular}

Table 4. Reliability analysis of ODAs factors in ORCs.

\begin{tabular}{|c|c|c|c|c|}
\hline Factors & Items & Details & Valid Observations & Alpha $(\alpha)$ \\
\hline ODAS1—Social activities & $\begin{array}{l}1 . \\
2 . \\
3 .\end{array}$ & $\begin{array}{l}\text { Visiting friends in this ORC } \\
\text { Visiting family members } \\
\text { Chatting with neighbors }\end{array}$ & 241 & 0.757 \\
\hline ODAS2-Leisure activities & $\begin{array}{l}4 . \\
5 . \\
6 . \\
7 . \\
8 .\end{array}$ & $\begin{array}{c}\text { Strolling } \\
\text { Walking with vigorous strides } \\
\text { Doing exercise (tai chi, square dance) } \\
\text { Using fitness equipment } \\
\text { Playing cards/Mahjong }\end{array}$ & 243 & 0.724 \\
\hline ODAS3-Utilitarian-type activities & $\begin{array}{l}9 . \\
10 . \\
11 . \\
12 . \\
13 .\end{array}$ & $\begin{array}{l}\text { Going to the post office } \\
\text { Going to the supermarket } \\
\text { Going to the market } \\
\text { Going to the bank } \\
\text { Going to the hospital }\end{array}$ & 255 & 0.798 \\
\hline ODAS4-Nature-exposure activities & $\begin{array}{l}14 . \\
15 . \\
16 .\end{array}$ & $\begin{array}{l}\text { Basking } \\
\text { Enjoying the grass and flowers } \\
\text { Having fresh air in the greeneries }\end{array}$ & 256 & 0.898 \\
\hline
\end{tabular}




\subsection{Correlation Analysis of $O E$ and $O D A s$}

The results of the correlation analysis show that there are significant associations between seniors' outdoor daily activities and OE factors, as shown in Table 5. Social activities have significant associations with five $\mathrm{OE}$ factors: layout (F3: 0.246), slip-resistance measures (F4: 0.245), noise (F5: -0.417), poor air quality (F6: 0.292), and cleaning (F11: $0.222)$. Leisure activities were revealed to significantly correlate with three OE factors: road accessibility (F2: 0.245), slip-resistance measures (F4: 0.272), and staff (F14: 0.293). Activities of daily living were positively significantly correlated with stairway accessibility (F1: 0.336), while negatively significantly correlated with poor air quality (F8: -0.269 ), cleaning (F11: -0.317 ), fitness equipment (F12: -0.427$)$, and seating (F13: -0.404$)$. Natureexposure activities have significant association with stairway accessibility (F1: 0.223), road accessibility (F2: 0.292), layout (F3: 0.365), greenery (F5: -0.422), poor air quality (F6: -0.287 ), cleaning (F11: 0.244), fitness equipment (F12: 0.235), and seating (F13: 0.236).

Table 5. Correlation between ODAs and factors of ODAs.

\begin{tabular}{|c|c|c|c|c|}
\hline \multirow{2}{*}{ Factors } & ODA1 & ODA2 & ODA3 & ODA4 \\
\hline & SA & LA & UTA & NEA \\
\hline ODAS1—Social activities & $1.000 * *$ & & & \\
\hline ODAS2_Leisure activities & $0.477^{* *}$ & $1.000^{* *}$ & & \\
\hline ODAS3-Outdoor UTA & $0.537^{* *}$ & $0.510^{* *}$ & $1.000^{* *}$ & \\
\hline ODAS4-Nature-exposure activities & $0.616^{* *}$ & $0.409^{* *}$ & $0.218^{*}$ & $1.000^{* *}$ \\
\hline F1-Stairway accessibility & 0.189 & 0.173 & $0.336^{* *}$ & $0.223^{* *}$ \\
\hline F2-Road accessibility & $0.232 * *$ & $0.256^{* *}$ & $0.157 *$ & $0.230 * *$ \\
\hline F3-Layout & $0.246^{* *}$ & 0.108 & $0.261^{* *}$ & $0.365^{* *}$ \\
\hline F4-Slip-resistance measures & $0.245^{* *}$ & $0.272^{* *}$ & 0.064 & 0.127 \\
\hline F5-Noise & $-0.417^{* *}$ & -0.138 & -0.221 & $-0.422 * *$ \\
\hline F6-Poor air quality & $-0.292^{* *}$ & 0.016 & $-0.269^{* *}$ & $-0.287^{* *}$ \\
\hline F7-Lighting & 0.060 & -0.070 & -0.120 & 0.160 \\
\hline F8-Greenery & $0.241^{* *}$ & 0.071 & $-0.429^{* *}$ & $0.252 * *$ \\
\hline F9-Handrail & 0.020 & -0.163 & 0.026 & 0.062 \\
\hline F10-Security & 0.006 & -0.073 & -0.019 & -0.023 \\
\hline F11-Cleaning & $0.222 * *$ & 0.019 & $-0.317^{* *}$ & $0.244^{* *}$ \\
\hline F12-Fitness equipment & 0.214 & 0.092 & $-0.427^{* *}$ & $0.235 * *$ \\
\hline F13-Seating & 0.185 & 0.158 & $-0.404^{* *}$ & $0.236^{* *}$ \\
\hline F14-Staff & -0.029 & $0.293^{* *}$ & -0.086 & -0.009 \\
\hline
\end{tabular}

Note: total sample size $=258$; SA—social activities; LA—leisure activities; ODAS—outdoor daily activities; NEA-nature-exposure activities. ${ }^{* *}$-Correlation is significant at the 0.01 level (2-tailed). * - Correlation is significant at the 0.05 level (2-tailed).

\subsection{Multiple Regression Analysis}

Four separate multiple regressions were conducted using a stepwise method to test the predictive power and relative contribution of the OE factors for each ODA [82,95]. Demographic factors, such as age gender and period of residence, were not included in the final models, since this research focused on the OE factors (see Table 6).

Social activities (ODA1) were positively associated with slip-resistance measures (F4), while negatively associated with noise (F5), explaining $22.2 \%$ of the variance in Model 1. In Model 2, leisure activities (ODA2) were positively associated with road accessibility (F2), slip-resistance measures (F4), greenery (F8), and staff (F14), explaining $22.3 \%$ of the variance. Model 3 showed that activities of daily living (ODA3) were negatively induced by greenery (F8) and seating (F13), while positively associated with stairway accessibility (F1) and slip-resistance measures (F4), accounting for 35.2\% of the variance. Model 4 revealed that nature-exposure activities were negatively associated with poor air quality (F6) and positively associated with layout (F3) and poor air quality (F6), explaining $16.4 \%$ of the variance. 
Table 6. Regression models of ODAs for seniors in ORCs.

\begin{tabular}{|c|c|c|c|c|c|c|c|c|c|}
\hline & Model & B & Std. Error & $\mathbf{t}$ & Sig. & VIF & $\mathbf{R}$ & Adjusted $R^{2}$ & $\begin{array}{c}\text { Significance } \\
\text { (ANOVA) }\end{array}$ \\
\hline 1. & \multicolumn{2}{|l|}{ Social activities } & \multicolumn{2}{|c|}{$\leftarrow$} & \multicolumn{5}{|c|}{ OE factors } \\
\hline & $($ Constant $)$ & 2.042 & 0.214 & 9.556 & 0.000 & & 0.373 & 0.121 & 0.000 \\
\hline & F4-Slip-resistance measures & 0.128 & 0.058 & 2.221 & 0.027 & 1.069 & & & \\
\hline & F5-Noise & -2.042 & 0.214 & -9.556 & 0.000 & 1.069 & & & \\
\hline \multirow[t]{6}{*}{2.} & \multicolumn{2}{|l|}{ Leisure activities } & \multicolumn{2}{|c|}{$\leftarrow$} & \multicolumn{5}{|c|}{ OE factors } \\
\hline & (Constant) & 1.281 & 0.303 & 4.229 & 0.000 & & 0.420 & 0.159 & 0.000 \\
\hline & F14-Staff & 0.242 & 0.100 & 2.411 & 0.017 & 1.474 & & & \\
\hline & F8-Greenery & 0.248 & 0.092 & 2.706 & 0.007 & 1.864 & & & \\
\hline & F4-Slip-resistance measures & 0.313 & 0.086 & 3.636 & 0.000 & 1.551 & & & \\
\hline & F2-Road accessibility & 0.219 & 0.089 & 2.466 & 0.015 & 1.443 & & & \\
\hline \multirow[t]{6}{*}{3.} & \multicolumn{2}{|l|}{ Activities of daily living } & \multicolumn{2}{|c|}{$\leftarrow$} & \multicolumn{5}{|c|}{ OE factors } \\
\hline & (Constant) & 0.285 & 0.209 & 10.751 & 0.000 & & 0.593 & 0.327 & 0.000 \\
\hline & F8-Greenery & -0.298 & 0.056 & -0.293 & 0.000 & 1.239 & & & \\
\hline & F1-Stairway accessibility & 0.157 & 0.060 & 0.637 & 0.010 & 1.109 & & & \\
\hline & F13-Seating & -0.108 & 0.041 & -0.626 & 0.010 & 1.196 & & & \\
\hline & F4-Slip-resistance measures & 0.120 & 0.052 & 0.313 & 0.023 & 1.264 & & & \\
\hline 4. & \multicolumn{2}{|c|}{ Nature-exposure activities } & \multicolumn{2}{|c|}{$\leftarrow$} & \multicolumn{5}{|c|}{ OE factors } \\
\hline & (Constant) & 1.629 & 0.303 & 5.370 & 0.000 & & 0.404 & 0.156 & 0.000 \\
\hline & F3-Layout & 0.398 & 0.088 & 4.531 & 0.000 & 1.074 & & & \\
\hline & F6-Poor air quality & -0.216 & 0.074 & -2.635 & 0.004 & 1.108 & & & \\
\hline & F8-Greenery & 0.168 & 0.090 & 1.865 & 0.036 & 1.108 & & & \\
\hline
\end{tabular}

Notes: missing data processing method: mean substitution; observations $=258$; Sig. $=$ significance; VIF = variance inflation factor.

\section{Discussion}

The results reveal in both correlation and regression analysis that four factors of accessibility, two factors of physical environment, and three factors of supporting facilities are associated with ODAs.

\subsection{Factors Significantely Associated with Social Activities}

Slip-resistance measures are revealed to be positively associated with social activities. Due to declining physical health, seniors are often worried about their personal safety. The slippery surface of the road can easily lead to younger adults falling, let alone frail seniors [96]. Seniors may hesitate to go out if they know there are many slippery surfaces in the area or may be encouraged to go outside if slip-resistant measures, such as anti-slip mats and non-slip tiles, are in place.

Hearing is one of the first senses to be affected by age, which starts to wane by the age of 40 [97]. Even for the seniors who have normal hearing, too high noise in ORCs, including life noise, transportation noise, construction noise, and traffic noise, makes it hard for seniors to clearly hear conversation-level voices. In addition to communication difficulties, too much noise will also induce negative feelings, such as depression and anxiety [98]. Hence, the social activities of seniors will often be hindered or even obstructed by severe noise.

\subsection{Factors Positively Associated with Leisure Activities}

Road accessibility is another OE factor associated with leisure activities in the outdoor living environment of ORCs. Seniors often need to walk along roads / paths to reach outdoor leisure activities or to simply take a stroll in ORCs. However, there are often many barriers including potholes and curbs due to lack of proper and timely maintenance. Seniors' physical functions decline with age and often find small obstacles or uneven surfaces to be hazardous [99,100]; uneven roads/paths are often reported by older adults [101]. Safety 
issues surrounding poorly maintained roads/paths will discourage seniors from walking for leisure or for brisk exercise. On the other hand, well maintained roads/paths can create safe and comfortable walking routes for seniors and encourage them to go outside for leisure activities in ORCs [77].

Slip-resistance measures, discussed above in relation to its association with seniors via social activities, were also revealed to be positively and significantly associated with leisure activities. Well-maintained roads/paths can encourage seniors to walk outside to take exercise, while poorly maintained roads/paths and slippery surfaces would make them hesitate to go outside [42]. Greenery is positively associated with leisure activities, which was shown by the regression analysis. Within an urban environment, greenery provides favorable living conditions [102], and seniors prefer to stay in their community and walk around green spaces during the time they exercise outside [103]. As such, it is suggested that local governments and councils focus on maintaining and increasing greenery-filled public areas that are convenient to walk in and are within easy walking distance of each residential building [104].

\subsection{Factors Associated with Utilitarian-Type Activities}

Elevators were not installed in most of the residential buildings of the OCRs in China [105]. Residents in ORCs have to go in and out of the building through the entrance and stairway in all the surveyed ORCs. Unlike younger adults, stairways present seniors with many difficulties; they may, for example, easily trip over obstacles left on the stairway and fall. Falls are the leading cause of both fatal and non-fatal injuries among seniors [106]. Hence, stairway accessibility is an important factor for seniors, which is confirmed by this study. Barriers in the building will decrease seniors' intention to take outdoor utilitariantype activities (UTA), including going to the market and post office. They will tend to stay at home and not go out to buy necessities, take a walk, or visit family members and friends. This inactivity can easily induce depression, stress, and anxiety [107].

Slip-resistance measures are revealed to be positively associated with outdoor UTA. Since seniors often need to walk on the road to go outside of the ORCs, any slippery surface on the road could be a serious hazard for them. Hence, seniors may have a fear of going outdoors due to the dangers of slippery surfaces [42,108].

Seating along the road and in recreational areas is an important facility for people to take a rest, and seat availability is a major concern for seniors [109]. However, it is interesting that seating was found to be negatively associated with UTA. A reasonable explanation for this finding would be that seniors who plan outdoor UTA might be tempted to take a rest on a comfortable seat and start chatting with neighbors and friends instead of continuing with their UTA; after all, most seniors have ample time to deal with personal issues after retirement. However, if the seating is not well maintained, they may only take a rest for a short while and then continue with their UTA.

Greenery was found to negatively promote outdoor UTA. As discussed above, favorable greenery has many physical and psychological benefits [110]. When going out to take UTA such as playing Mahjong and square dancing, seniors might be attracted by the greenery in the neighborhood and, thus, change their UTA plan.

\subsection{Factors Significantly Associated with Nature-Exposure Activities}

Good greenery can provide a collection of green bushes, leaves, and flowers that can increase an individual's perspective of their living environment, while unkempt greenery could evoke a negative response from seniors [38,111]. Hence, seniors would like to undertake activities that expose them to nature, including enjoying the benefits of good scenery and sunshine [71,112]. Conversely, seniors will not be willing to go outside for nature-exposure activities if outdoor greenery is poor and insufficient.

Poor air quality was revealed in this study to deter nature-exposure activities. Fresh air can encourage seniors to go outside, since the indoor quality of air is usually poor due to inadequate ventilation and domestic odors. Seniors can also receive physical benefits from 
fresh air. However, if the outside air quality is poor (due to domestic trash, for example), seniors may choose not to partake in nature-exposure activities.

Layout can also be positively and significantly associated with seniors' nature-exposure activities. A poor layout is regarded as posing potential problems and hazards for seniors $[113,114]$. Seniors would hesitate to take nature-exposure activities when ORCs have a poor layout, such as greenery too far from seniors' residences, insufficient public spaces, or too many vehicles in the area. However, a favorable layout with safe, easily accessible public areas can create a satisfying living environment for seniors.

\section{Limitations of the Study}

Although several important findings emerged from this research, the following limitations should be noted. Firstly, the questionnaire survey's relatively small sample size and self-reporting subjective measurement for environmental factors may limit the generalizability of the results and call into question the potential common method variance and the validity of data. However, the following factors decrease such possibility: (1) all scales for measurement of $\mathrm{OE}$ factors and ODAs were adopted based on an extensive literature review; (2) the senior respondents in this study were intentionally selected with different backgrounds, such as age, gender, and health status; (3) all respondents selected in this research came from different ORCs and different old districts in Nanjing city; (4) all the senior respondents had lived in their ORCs for at least one year and, thus, had a direct experience of the $\mathrm{OE}$ in their community; (5) all the factors adopted in this study were statistically tested as reliable (greater than 0.6 ). The research team is, therefore, confident that the results of this research have not been biased by different responses to the measured variables and can be used as baseline information for further larger-scale studies with regards to the association between OE factors in ORCs and the quality of life of senior residents. It can also be treated as a reliable reference for research with different types of residential communities, such as settlement building communities, new-build residential communities, and public rental housing.

Secondly, the demographic questions in the questionnaire acquired age, gender, period of residence, educational level, marital status, and faith. The financial and living arrangement of the older adults were not included for the following reasons: (1) this research mainly aims to investigate the important $\mathrm{OE}$ factors influencing the ODAs of older adults and provide suggestions to improve the OE for older adults in ORCs during the process of renewal of ORCs in cities and towns in China; therefore, the OE factors were more focused on; (2) although financial and living arrangements are essential to predict older adults' health behaviors, they have little relation with the outdoor environment, which is a public area rather than a private place; (3) older adults have to stay in or pass through the $\mathrm{OE}$ in ORCs to take part in ODAs, regardless of their financial and living arrangement. However, these two important factors should be considered in future research on the association between indoor environment and the quality of life or safety of older adults.

Thirdly, mean substitution (MS) was adopted in this study to deal with missing data. However, since the MS method has been criticized in some studies (e.g., [115]), the effectiveness of the data analysis in this study is questionable. It is, therefore, suggested to apply multiple imputation and the full information maximum likelihood method in further studies [115].

Fourthly, Bonferroni adjustments were not used during the regression analysis, and the alpha criterion was set at 0.05 , which might increase the type-I error rate. However, adopting Bonferroni adjustments may lead to a type-II error [116]. This method is too conservative [117], especially when there is a large number of comparisons to be made.

\section{Conclusions and Implications}

This research revealed some important findings: there is a significant association between social activities and slip-resistance measures as well as noise in ORCs; leisure activities can be associated with road/path accessibility, slip-resistance measures, greenery, 
and staff; utilitarian-type activities are associated with stairway accessibility, slip-resistance measures, greenery, and seating; nature-exposure activities are associated with layout, air quality, and greenery.

Based on the findings of this research, practical measures can be implemented to provide a quality outdoor environment for seniors in the process of renewing ORCs in China. Given the association between road accessibility and leisure activities, asphalt road surfaces are advised instead of concrete and brick, since it has the advantages of good mechanical strength, a smooth surface, and needing relatively little maintenance [118]. Ramps should be built along pathways instead of steps. Due to the association between slipresistance measures and three types of ODAs, the following strategies can be adopted to encourage the ODAs of seniors: scattering straw or salt on wet or snowy days and cleaning up immediately after the rain or when the snow stops. However, the health situation and walking ability of the older respondents may influence the final model regarding ODAs and OE factors. It is suggested that future studies explore the association between ODAs and $\mathrm{OE}$ factors under different types of health and walking abilities of older residents.

Supplementary Materials: The following are available online at https:/ / www.mdpi.com/article/10 .3390/ijerph18147500/s1, File S1: Questionnaire development, File S2: Levene's Test.

Author Contributions: Conceptualization, S.Y. and J.H.; methodology, S.Y.; software, S.Y.; investigation, S.Y. and N.G.; resources, C.Z.; data curation, S.Y. and Y.S.; writing-original draft preparation, S.Y. and C.Z.; writing-review and editing, J.H.; supervision, J.H.; project administration, S.Y. and J.H.; funding acquisition, S.Y. All authors have read and agreed to the published version of the manuscript.

Funding: This research was funded by China's Ministry of Education Project of Humanities and Social Sciences (grant number 17YJCZH232), supported by the Natural Science Research Project of Higher Education Institutions of Jiangsu Province (KZ2019043) and sponsored by Qing Lan Project of Jiangsu Province.

Institutional Review Board Statement: This research was approved in 2019 by the Ethics Committee of the Institute of Built Environment and Health, Sanjiang University (approval number IBEH2019.012, March 2019). The study was carefully conducted according to the guidelines of the Declaration of Helsinki.

Informed Consent Statement: Informed consent was obtained from all subjects involved in the study.

Data Availability Statement: Data are available on request due to privacy restrictions. The data presented in this study may be available on request from the corresponding author and with the authorization of the funding origination.

Conflicts of Interest: The authors declare no conflict of interest.

\section{References}

1. National Bureau of Statistics. Bulletin of the Seventh National Census. Available online: http://www.stats.gov.cn/tjsj/zxfb/2021 05/t20210510_1817181.html (accessed on 16 June 2021).

2. China Development Foundation. Aging Population: China's Development Trend and Policy Options; China Development Press: Beijing, China, 2020.

3. Hui, E.C.M.; Zheng, X.; Hu, J. Housing Price, Elderly Dependency and Fertility Behaviour. Habitat Int. 2012, 36, $304-311$. [CrossRef]

4. Zhang, C.; Xue, Y.; Zhao, H.; Zheng, X.; Zhu, R.; Du, Y.; Zheng, J.; Yang, T. Prevalence and Related Influencing Factors of Depressive Symptoms among Empty-Nest Elderly in Shanxi, China. J. Affect. Disord. 2019, 245, 750-756. [CrossRef]

5. Song, Y. Losing an Only Child: The One-Child Policy and Elderly Care in China. Reprod. Health Matters 2014, 22, 113-124. [CrossRef]

6. Hui, E.C.M.; Wong, F.K.W.; Chung, K.W.; Lau, K.Y. Housing Affordability, Preferences and Expectations of Elderly with Government Intervention. Habitat Int. 2014, 43, 11-21. [CrossRef]

7. Xu, Y.; Zhang, X. The Residential Resettlement in Suburbs of Chinese Cities: A Case Study of Changsha. Cities 2017, 69, 46-55. [CrossRef]

8. General Office of the State Council. Guiding Opinions of the General Office of the State Council on Promoting the Renewal of Old Residential Communities in Cities and Tours in an All-Round Way. Available online: http://www.rh.gov.cn/jgsz/bmpd/szfhcxjsj/ gzdt/202009/t20200923_63350112.html (accessed on 10 December 2020). 
9. Rodiek, S.; Nejati, A.; Bardenhagen, E.; Lee, C.; Senes, G. The Seniors' Outdoor Survey: An Observational Tool for Assessing Outdoor Environments at Long-Term Care Settings. Gerontologist 2016, 56, 222-233. [CrossRef] [PubMed]

10. Liu, C.S.; Liu, L.L.; Shi, B.; Ji, W.Y. Existing problems and solutions of property management in old communities. Urban Probl. 2012, 9, 83-85.

11. Wu, Y.S. The renewal of the old residential community is a good news for the older adults. China Society News, 14 May 2020.

12. Hino, K.; Usui, H.; Hanazato, M. Three-Year Longitudinal Association between Built Environmental Factors and Decline in Older Adults' Step Count: Gaining Insights for Age-Friendly Urban Planning and Design. Int. J. Environ. Res. Public Health 2020, 17, 4247. [CrossRef]

13. Gobbens, R.J.; van Assen, M.A. Associations of Environmental Factors with Quality of Life in Older Adults. Gerontologist 2018, 58, 101-110. [CrossRef]

14. Park, S.; Lee, S. Age-Friendly Environments and Life Satisfaction among South Korean Elders: Person-Environment Fit Perspective. Aging Ment. Health 2017, 21, 693-702. [CrossRef]

15. Gargiulo, C.; Zucaro, F.; Gaglione, F. A Set of Variables for the Elderly Accessibility in Urban Areas. TeMA J. Land Use Mobil. Environ. 2018, 53-66. [CrossRef]

16. Van Cauwenberg, J.; De Bourdeaudhuij, I.; De Meester, F.; Van Dyck, D.; Salmon, J.; Clarys, P.; Deforche, B. Relationship between the Physical Environment and Physical Activity in Older Adults: A Systematic Review. Health Place 2011, 17, 458-469. [CrossRef]

17. Garin, N.; Olaya, B.; Miret, M.; Ayuso-Mateos, J.L.; Power, M.; Bucciarelli, P.; Haro, J.M. Built Environment and Elderly Population Health: A Comprehensive Literature Review. Clin. Pract. Epidemiol. Ment. Health CP EMH 2014, 10, 103. [CrossRef]

18. Leung, M.; Liang, Q. Developing Structural Facilities Management-Quality of Life Models for the Elderly in the Common Areas of Public and Subsidized Housings. Habitat Int. 2019, 94, 102067. [CrossRef]

19. Wu, X.; Li, H. Gated Communities and Market-Dominated Governance in Urban China. J. Urban Plan. Dev. 2020, 146, 04020025 [CrossRef]

20. Gu, T.; Li, D.; Zhu, S.; Wang, Y. Does Sponge-Style Old Community Renewal Lead to a Satisfying Life for Residents? An Investigation in Zhenjiang, China. Habitat Int. 2019, 90, 102004. [CrossRef]

21. Gu, T.; Li, D.; Zhang, M.; Jiang, Y. Influencing Factors of Residents' Intention to Participate in the Governance of Old Community Renewal: A Case Study of Nanjing. Int. J. Civ. Environ. Eng. 2020, 14, 239-244.

22. Li, D.; Du, B.; Zhu, J. Evaluating Old Community Renewal Based on Emergy Analysis: A Case Study of Nanjing. Ecol. Model. 2021, 449, 109550. [CrossRef]

23. Zhu, S.; Li, D.; Jiang, Y. The Impacts of Relationships between Critical Barriers on Sustainable Old Residential Neighborhood Renewal in China. Habitat Int. 2020, 103, 102232. [CrossRef]

24. Arenghi, A.; Garofolo, I.; Laurìa, A. On the Relationship between "Universal" and "Particular" in Architecture. Stud. Health Technol. Inform. 2016, 229, 31-39. [PubMed]

25. Ho, D.C.-W.; Chau, K.-W.; King-Chung Cheung, A.; Yau, Y.; Wong, S.-K.; Leung, H.-F.; Siu-Yu Lau, S.; Wong, W.-S. A Survey of the Health and Safety Conditions of Apartment Buildings in Hong Kong. Build. Environ. 2008, 43, 764-775. [CrossRef] [PubMed]

26. Demura, S.; Yamada, T.; Kasuga, K. Severity of Injuries Associated with Falls in the Community Dwelling Elderly are Not Affected by Fall Characteristics and Physical Function Level. Arch. Gerontol. Geriatr. 2012, 55, 186-189. [CrossRef]

27. Bahrehmand, A.; Batard, T.; Marques, R.; Evans, A.; Blat, J. Optimizing Layout Using Spatial Quality Metrics and User Preferences. Graph. Models 2017, 93, 25-38. [CrossRef]

28. Giles-Corti, B.; Foster, S.; Kooshari, M.J.; Francis, J.; Hooper, P. The Influence Oif Urban Design and Planning on Physical Activity. In The Routledge Handbook of Planing for Health and Well-Being; Routledge: Oxfordshire, UK, 2015; pp. 121-135.

29. Li, K.; Zhang, Y.; Zhao, L. Outdoor Thermal Comfort and Activities in the Urban Residential Community in a Humid Subtropical Area of China. Energy Build. 2016, 133, 498-511. [CrossRef]

30. Devkota, S.; Anderson, B.; Soiza, R.L.; Myint, P.K. Prevalence and Determinants of Frailty and Associated Comorbidities among Older Gurkha Welfare Pensioners in Nepal. Geriatr. Gerontol. Int. 2017, 17, 2493-2499. [CrossRef] [PubMed]

31. D'souza, S.A.; Shringarpure, A.; Karol, J. Circumstances and Consequences of Falls in Indian Older Adults. Indian J. Occup. Ther. 2008, 40, 3-11.

32. Annear, M.; Keeling, S.; Wilkinson, T.I.M.; Cushman, G.; Gidlow, B.O.B.; Hopkins, H. Environmental Influences on Healthy and Active Ageing: A Systematic Review. Ageing Soc. 2014, 34, 590. [CrossRef]

33. Indraganti, M.; Rao, K.D. Effect of Age, Gender, Economic Group and Tenure on Thermal Comfort: A Field Study in Residential Buildings in Hot and Dry Climate with Seasonal Variations. Energy Build. 2010, 42, 273-281. [CrossRef]

34. Lu, X.; Park, N.-K.; Ahrentzen, S. Lighting Effects on Older Adults' Visual and Nonvisual Performance: A Systematic Review. J. Hous. Elder. 2019, 33, 298-324. [CrossRef]

35. Oh, M.; Shin, K.; Kim, K.; Shin, J. Influence of Noise Exposure on Cardiocerebrovascular Disease in Korea. Sci. Total Environ. 2019, 651, 1867-1876. [CrossRef]

36. Sung, J.H.; Lee, J.; Park, S.J.; Sim, C.S. Relationship of Transportation Noise and Annoyance for Two Metropolitan Cities in Korea: Population Based Study. PLoS ONE 2016, 11, e0169035. [CrossRef] [PubMed]

37. Padhi, B.; Padhy, P. Assessment of Intra-Urban Variability in Outdoor Air Quality and its Health Risks. Inhal. Toxicol. 2008, 20, 973-979. [CrossRef] [PubMed] 
38. Abraham, A.; Sommerhalder, K.; Abel, T. Landscape and Well-Being: A Scoping Study on the Health-Promoting Impact of Outdoor Environments. Int. J. Public Health 2010, 55, 59-69. [CrossRef] [PubMed]

39. Milligan, C.; Gatrell, A.; Bingley, A. 'Cultivating Health': Therapeutic Landscapes and Older People in Northern England. Soc. Sci. Med. 2004, 58, 1781-1793. [CrossRef]

40. Ishihara, K.; Nagamachi, M.; Komatsu, K.; Ishihara, S.; Ichitsubo, M.; Mikami, F.; Osuga, Y.; Imamura, K.; Osaki, H. Handrails for the Elderly: A Survey of the Need for Handrails and Experiments to Determine the Optimal Size of Staircase Handrails. Gerontechnology 2002, 1, 175-189. [CrossRef]

41. Maki, B.E.; Perry, S.D.; Mcllroy, W.E. Efficacy of Handrails in Preventing Stairway Falls: A New Experimental Approach. Saf. Sci. 1998, 28, 189-206. [CrossRef]

42. Rantakokko, M.; Mänty, M.; Iwarsson, S.; Törmäkangas, T.; Leinonen, R.; Heikkinen, E.; Rantanen, T. Fear of Moving Outdoors and Development of Outdoor Walking Difficulty in Older People. J. Am. Geriatr. Soc. 2009, 57, 634-640. [CrossRef]

43. Rutala, W.A.; Weber, D.J. Monitoring and Improving the Effectiveness of Surface Cleaning and Disinfection. Am. J. Infect. Control. 2016, 44, e69-e76. [CrossRef]

44. Ememe, O.N.; Onwuchekwa, G.U.; Onuigbo, N. Availability and Utilization of Physical Facilities in Abia State Primary Schools. J. Resour. Distinct. 2012, 2, 214-222.

45. Harris, A.; Waller, E.; Wishart, S. Good Practice Road Safety Education and Community Road Safety. In Proceedings of the Australasian College of Road Safety Conference 2013, Adelaide, Australia, 6-8 November 2013.

46. Burton, E.; Mitchell, L. Inclusive Urban Design—Streets for Life; Elsevierer: Oxford, UK, 2006; ISBN 9780750664585.

47. Day, R. Local Environments and Older People's Health: Dimensions from a Comparative Qualitative Study in Scotland. Health Place 2008, 14, 299-312. [CrossRef]

48. Paris, D.E.; Kangari, R. Multifamily Affordable Housing: Residential Satisfaction. J. Perform. Constr. Facil. 2005, 19, 138-145. [CrossRef]

49. Paris, D.E. Impact of Property Management Services on Affordable Housing Residents in Atlanta, Georgia. J. Perform. Constr. Facil. 2006, 20, 222-228. [CrossRef]

50. Yung, E.H.K.; Conejos, S.; Chan, E.H.W. Social Needs of the Elderly and Active Aging in Public Open Spaces in Urban Renewal. Cities 2016, 52, 114-122. [CrossRef]

51. Li, Y.-P.; Lin, S.-I.; Chen, C.-H. Gender Differences in the Relationship of Social Activity and Quality of Life in CommunityDwelling Taiwanese Elders. J. Women Aging 2011, 23, 305-320. [CrossRef] [PubMed]

52. Takahashi, T.; Ishida, K.; Hirose, D.; Nagano, Y.; Okumiya, K.; Nishinaga, M.; Matsubayashi, K.; Doi, Y.; Tani, T.; Yamamoto, H. Trunk Deformity is Associated with a Reduction in Outdoor Activities of Daily Living and Life Satisfaction in CommunityDwelling Older People. Osteoporos. Int. 2005, 16, 273-279. [CrossRef] [PubMed]

53. Wood, C.J.; Smyth, N. The Health Impact of Nature Exposure and Green Exercise across the Life Course: A Pilot Study. Int. J. Environ. Health Res. 2020, 30, 226-235. [CrossRef]

54. Yamashita, T.; Bardo, A.R.; Liu, D. Time Spent on Beneficial Leisure Activities among Elder Caregivers in Their Third Age. Leis. Sci. 2018, 40, 356-373. [CrossRef]

55. Wen, J.; Peng, H.M.; Wang, T.H. Preferential Daily Activities of Community-Dwelling Older Adults. Chin. J. Gerontol. 2010, 30, 1865-1867.

56. Lam, L.C.; Chan, W.C.; Leung, T.; Fung, A.W.; Leung, E.M. Would Older Adults with Mild Cognitive Impairment Adhere to and Benefit from a Structured Lifestyle Activity Intervention to Enhance Cognition? A Cluster Randomized Controlled Trial. PLoS ONE 2015, 10, e0118173. [CrossRef] [PubMed]

57. Bowling, A.; Stafford, M. How Do Objective and Subjective Assessments of Neighbourhood Influence Social and Physical Functioning in Older Age? Findings from a British Survey of Ageing. Soc. Sci. Med. 2007, 64, 2533-2549. [CrossRef]

58. Sugiyama, T.; Thompson, C.W. Environmental Support for Outdoor Activities and Older People's Quality of Life. J. Hous. Elder. 2006, 19, 167-185. [CrossRef]

59. Vogelsang, E.M. Older Adult Social Participation and its Relationship with Health: Rural-Urban Differences. Health Place 2016, 42, 111-119. [CrossRef]

60. Giebel, C.M.; Challis, D.J.; Montaldi, D. A Revised Interview for Deterioration in Daily Living Activities in Dementia Reveals the Relationship between Social Activities and Well-Being. Dementia 2016, 15, 1068-1081. [CrossRef] [PubMed]

61. Brajša-Žganec, A.; Merkaš, M.; Šverko, I. Quality of Life and Leisure Activities: How Do Leisure Activities Contribute to Subjective Well-Being? Soc. Indic. Res. 2011, 102, 81-91. [CrossRef]

62. Van der Meer, M.J. The Sociospatial Diversity in the Leisure Activities of Older People in the Netherlands. J. Aging Stud. 2008, 22, 1-12. [CrossRef]

63. Lee, D.R.; Kawas, C.H.; Gibbs, L.; Corrada, M.M. Prevalence of Frailty and Factors Associated with Frailty in Individuals Aged 90 and Older: The 90+ Study. J. Am. Geriatr. Soc. 2016, 64, 2257-2262. [CrossRef] [PubMed]

64. Kim, J.W.; Lee, H.W.; Lee, I.-G.; Jeon, J.-K.; Ryu, C.; Park, S.H.; Jung, S.-C.; Park, Y.-K. Influence of Reaction Conditions on Bio-Oil Production from Pyrolysis of Construction Waste Wood. Renew. Energy 2014, 65, 41-48. [CrossRef]

65. Verghese, J.; Lipton, R.B.; Katz, M.J.; Hall, C.B.; Derby, C.A.; Kuslansky, G.; Ambrose, A.F.; Sliwinski, M.; Buschke, H. Leisure Activities and the Risk of Dementia in the Elderly. N. Engl. J. Med. 2003, 348, 2508-2516. [CrossRef] [PubMed] 
66. Mahmood, A.; Chaudhury, H.; Michael, Y.L.; Campo, M.; Hay, K.; Sarte, A. A Photovoice Documentation of the Role of Neighborhood Physical and Social Environments in Older Adults' Physical Activity in Two Metropolitan Areas in North America. Soc. Sci. Med. 2012, 74, 1180-1192. [CrossRef] [PubMed]

67. Portegijs, E.; Rantakokko, M.; Viljanen, A.; Rantanen, T.; Iwarsson, S. Perceived and Objective Entrance-Related Environmental Barriers and Daily out-of-Home Mobility in Community-Dwelling Older People. Arch. Gerontol. Geriatr. 2017, 69, 69-76. [CrossRef]

68. Ward Thompson, C. Activity, Exercise and the Planning and Design of Outdoor Spaces. J. Environ. Psychol. 2013, 34, 79-96. [CrossRef]

69. Dutton, R. The Built Housing Environment, Wellbeing, and Older People. In Wellbeing: A Complete Reference Guide, Wellbeing and the Environment; Wiley-Blackwell: West Sussex, UK, 2014; pp. 1-38.

70. White, M.P.; Alcock, I.; Grellier, J.; Wheeler, B.W.; Hartig, T.; Warber, S.L.; Bone, A.; Depledge, M.H.; Fleming, L.E. Spending at Least 120 Minutes a Week in Nature is Associated with Good Health and Wellbeing. Sci. Rep. 2019, 9, 7730. [CrossRef]

71. Freeman, C.; Waters, D.L.; Buttery, Y.; van Heezik, Y. The Impacts of Ageing on Connection to Nature: The Varied Responses of Older Adults. Health Place 2019, 56, 24-33. [CrossRef]

72. Korpela, K.; De Bloom, J.; Sianoja, M.; Pasanen, T.; Kinnunen, U. Nature at Home and at Work: Naturally Good? Links between Window Views, Indoor Plants, Outdoor Activities and Employee Well-Being over One Year. Landsc. Urban Plan. 2017, 160, 38-47. [CrossRef]

73. MacKerron, G.; Mourato, S. Happiness is Greater in Natural Environments. Glob. Environ. Chang. 2013, 23, 992-1000. [CrossRef]

74. Shanahan, D.F.; Franco, L.; Lin, B.B.; Gaston, K.J.; Fuller, R.A. The Benefits of Natural Environments for Physical Activity. Sports Med. 2016, 46, 989-995. [CrossRef]

75. Wen, J.; Peng, H.M.; Wang, D.H. A study on the daily activity preference of the elderly in community. Chin. J. Gerontol. 2010, 30, 1865-1867.

76. China State Council. Property Management Regulation. Available online: http://www.gov.cn/gongbao/content/2016/content_51 39402.htm (accessed on 10 October 2020).

77. Yu, S.; Liu, Y.; Cui, C.; Xia, B. Influence of Outdoor Living Environment on Elders' Quality of Life in Old Residential Communities. Sustainability 2019, 11, 6638. [CrossRef]

78. Department of Housing and Urban-Rural Development of Jiangsu Province. Evaluation Standards for Service Quality of Provincial Demonstration Facilities Management Projects in Jiangsu Province. Available online: http://jsszfhcxjst.jiangsu.gov.cn/art/2019/1/1 7/art_49384_8895272.html (accessed on 26 March 2021).

79. Leung, M.; Yu, J.; Yu, S. Investigating Key Components of the Facilities Management of Residential Care and Attention Homes. Facilities 2012, 30, 611-629. [CrossRef]

80. Zhao, X.M.; Guo, W.W.; Shi, J.R. Community Outdoor Environment Elements Suitable for Aging Allocation Model Based on the Types of Older People's Daily Activities. Archit. J. 2017, 2, 48-52.

81. Leung, M.; Yu, J.; Chow, H. Impact of Indoor Facilities Management on the Quality of Life of the Elderly in Public Housing. Facilities 2016, 34, 564-579. [CrossRef]

82. Leung, M.; Famakin, I.O.; Olomolaiye, P. Effect of Facilities Management Components on the Quality of Life of Chinese Elderly in Care and Attention Homes. Facilities 2017, 35, 270-285. [CrossRef]

83. Leung, M.; Famakin, I.; Kwok, T. Relationships between Indoor Facilities Management Components and Elderly People's Quality of Life: A Study of Private Domestic Buildings. Habitat Int. 2017, 66, 13-23. [CrossRef]

84. Brownson, R.C.; Chang, J.J.; Eyler, A.A.; Ainsworth, B.E.; Kirtland, K.A.; Saelens, B.E.; Sallis, J.F. Measuring the Environment for Friendliness Toward Physical Activity: A Comparison of the Reliability of 3 Questionnaires. Am. J. Public Health 2004, 94, 473-483. [CrossRef]

85. Laura, N.; Gitlin, S.M.M.; Mann, W.; Tomit, M. Factors Associated with Home Environmental Problems among Community-Living Older People. Disabil. Rehabil. 2001, 23, 777-787. [CrossRef]

86. Sun, Y.X. Study on the Planning and Layout of Commercial Residential Districts in Small Towns in Nanxian. Master's Thesis, Hunan Normal University, Changsha, China, 2012.

87. Ma, J.; Li, C.; Kwan, M.-P.; Chai, Y. A Multilevel Analysis of Perceived Noise Pollution, Geographic Contexts and Mental Health in Beijing. Int. J. Environ. Res. Public Health 2018, 15, 1479. [CrossRef]

88. Sun, M.X. Research on Influencing Factors and Prediction of Air Quality in Wujiaqu City. Master's Thesis, Shihezi University, Shihezi, China, 2016.

89. Leung, M.; Liang, Q.; Pynoos, J. The Effect of Facilities Management of Common Areas on the Environment Domain of Quality of Life or Older People in Private Buildings. Facilities 2019, 37, 234-250. [CrossRef]

90. Tang, R.P. Analysis of the Problems and Countermeasures in the Safety Management of Public Sports Facilities in Urban Communities. Master's Thesis, Hunan Normal University, Changsha, China, 2018.

91. Tang, S.R. Research on the Current Situation and Countermeasures of the Humanized Design of Outdoor Public Space Environment in the Land-Lost Farmers Settlement Community. Master's Thesis, Sichuan Agricultural University, Chengdu, China, 2014.

92. Hayuni, G.; Hasson-Ohayon, I.; Goldzweig, G.; Bar Sela, G.; Braun, M. Between Empathy and Grief: The Mediating Effect of Compassion Fatigue among Oncologists. Psychooncology 2019, 28, 2344-2350. [CrossRef] [PubMed] 
93. Hair, J.F. Multivariate Data Analysis; Prentice Hall: Upper Saddle River, NJ, USA, 2009.

94. Ho, R. Handbook of Univariate and Multivariate Data Analysis with IBM SPSS; CRC Press: Los Angeles, LA, USA, 2013.

95. Pallant, J. SPSS Survival Manual: A Step by Step Guide to Data Analysis Using IBM SPSS; Routledge: Oxon, UK, 2020.

96. Janakiraman, B.; Temesgen, M.H.; Jember, G.; Gelaw, A.Y.; Gebremeskel, B.F.; Ravichandran, H.; Worku, E.; Abich, Y.; Yilak, F.; Belay, M. Falls among Community-Dwelling Older Adults in Ethiopia; A Preliminary Cross-Sectional Study. PLoS ONE 2019, 14, e0221875. [CrossRef]

97. Van Hoof, J.; Kort, H.S.M.; Duijnstee, M.S.H.; Rutten, P.G.S.; Hensen, J.L.M. The Indoor Environment and the Integrated Design of Homes for Older People with Dementia. Build. Environ. 2010, 45, 1244-1261. [CrossRef]

98. Jayakody, D.M.; Almeida, O.P.; Speelman, C.P.; Bennett, R.J.; Moyle, T.C.; Yiannos, J.M.; Friedland, P.L. Association between Speech and High-Frequency Hearing Loss and Depression, Anxiety and Stress in Older Adults. Maturitas 2018, 110, 86-91. [CrossRef] [PubMed]

99. Miller, E.; Wightman, E.; Rumbolt, K.; McConnell, S.; Berg, K.; Devereaux, M.; Campbell, F. Management of Fall-Related Injuries in the Elderly: A Retrospective Chart Review of Patients Presenting to the Emergency Department of a Community-Based Teaching Hospital. Physiother. Can. 2009, 61, 26-37. [CrossRef]

100. Hillsdon, M.M.; Brunner, E.J.; Guralnik, J.M.; Marmot, M.G. Prospective Study of Physical Activity and Physical Function in Early Old Age. Am. J. Prev. Med. 2005, 28, 245-250. [CrossRef]

101. Cheng, L.; Caset, F.; De Vos, J.; Derudder, B.; Witlox, F. Investigating Walking Accessibility to Recreational Amenities for Elderly People in Nanjing, China. Transp. Res. Part D Transp. Environ. 2019, 76, 85-99. [CrossRef]

102. Seferyan, L.A.; Kondrateva, T.N.; Morozov, V.E.; Leusenko, I.V. Qualitative State Improvement of Public and Courtyard Areas in Terms of Rostov-on-Don. In IOP Conference Series: Materials Science and Engineering; IOP Publishing: Bristol, UK, 2019; Volume 698, p. 055004.

103. Barton, H.; Tsourou, C. Healthy Urban Planning; Routledge: New York, NY, USA, 2013; ISBN 9781135159368.

104. Takano, T.; Nakamura, K.; Watanabe, M. Urban Residential Environments and Senior Citizens' Longevity in Megacity Areas: The Importance of Walkable Green Spaces. J. Epidemiol. Community Health 2002, 56, 913-918. [CrossRef]

105. Niu, Y.; Na, L.; Jin, C.; Chen, D.; Ding, H. Activity Outside the Home, Environmental Barriers, and Healthy Aging for CommunityDwelling Elderly Individuals in China. Bioence Trends 2017, 11, 603-605. [CrossRef] [PubMed]

106. Carande-Kulis, V.; Stevens, J.A.; Florence, C.S.; Beattie, B.L.; Arias, I. A Cost-Benefit Analysis of Three Older Adult Fall Prevention Interventions. J. Saf. Res. 2015, 52, 65-70. [CrossRef]

107. Stanczykiewicz, B.; Banik, A.; Knoll, N.; Keller, J.; Hohl, D.H.; Rosińczuk, J.; Luszczynska, A. Sedentary Behaviors and Anxiety among Children, Adolescents and Adults: A Systematic Review and Meta-Analysis. BMC Public Health 2019, 19, 1-22. [CrossRef] [PubMed]

108. Kulkarni, S.; Gadkari, R.; Nagarkar, A. Risk Factors for Fear of Falling in Older Adults in India. J. Public Health 2020, $28,123-129$. [CrossRef]

109. He, S.Y.; Cheung, Y.H.; Tao, S. Travel Mobility and Social Participation among Older People in a Transit Metropolis: A SocioSpatial-Temporal Perspective. Transp. Res. Part A Policy Pract. 2018, 118, 608-626. [CrossRef]

110. Finlay, J.; Franke, T.; McKay, H.; Sims-Gould, J. Therapeutic Landscapes and Wellbeing in Later Life: Impacts of Blue and Green Spaces for Older Adults. Health Place 2015, 34, 97-106. [CrossRef]

111. Van Cauwenberg, J.; De Bourdeaudhuij, I.; Clarys, P.; De Geus, B.; Deforche, B. Older Adults' Environmental Preferences for Transportation Cycling. J. Transport. Health 2019, 13, 185-199. [CrossRef]

112. Scott, T.L.; Masser, B.M.; Pachana, N.A. Exploring the Health and Wellbeing Benefits of Gardening for Older Adults. Ageing Soc. 2015, 35, 2176. [CrossRef]

113. Govender, T.; Barnes, J.M.; Pieper, C.H. Housing Conditions, Sanitation Status and Associated Health Risks in Selected Subsidized Low-Cost Housing Settlements in Cape Town, South Africa. Habitat Int. 2011, 35, 335-342. [CrossRef]

114. Zamora, F.M.V.; Kloseck, M.; Fitzsimmons, D.A.; Zecevic, A.; Fleming, P. Use of Community Support and Health Services in an Age-Friendly City: The Lived Experiences of the Oldest-Old. Cities Health 2020, 4, 107-116. [CrossRef]

115. Schlomer, G.L.; Bauman, S.; Card, N.A. Best Practices for Missing Data Management in Counseling Psychology. J. Couns. Psychol. 2010, 57, 1-10. [CrossRef]

116. Nakagawa, S. A Farewell to Bonferroni: The Problems of Low Statistical Power and Publication Bias. Behav. Ecol. 2004, 15, 1044-1045. [CrossRef]

117. Posch, M.; Futschik, A. A Uniform Improvement of Bonferroni-Type Tests by Sequential Tests. J. Am. Stat. Assoc. 2008, 103, 299-308. [CrossRef]

118. Zhu, Y.T.; Lei, M.J. The Application of Assets Evaluation in Analysis of Asphalt Pavement Maintenance Technology. Appl. Mech. Mater. 2011, 97-98, 347-351. [CrossRef] 